\title{
THE IMPACT OF POWER AND RELATIONSHIP QUALITY ON VALUE CREATION AND APPROPRIATION IN BUYER-SUPPLIER RELATIONSHIPS: THE CASE OF MOROCCAN COMPANIES
}

\author{
DOI: 10.17261/Pressacademia.2019.1130 \\ JMML-V.6-ISS.3-2019(5)-p.175-196
}

\author{
Mdarhri Alaoui Saad ${ }^{1}$, Amine Noureddine ${ }^{2}$ \\ ${ }_{1}^{1}$ Abdelmalek Assaadi University, National School of Trade and Management of Tangier, Morocco. \\ saadinho7@hotmail.com; ORCID: 0000-0002-2119-7784 \\ 2 Abdelmalek Assaadi University, National School of Trade and Management of Tangier, Morocco. \\ noureddineamine@yahoo.fr ORCID: 0000-0002-8045-8374
}

Date Received: June 11, 2019

Date Accepted: September 24, 2019

To cite this document

Saâd, M., A., Noureddine, A., (2019). The impact of power and relationship quality on value creation and appropriation in buyer-supplier relationships: the case of Moroccan companies. Journal of Management, Marketing and Logistics (JMML), V.6(3), p.175-196

Permemant link to this document: http://doi.org/10.17261/Pressacademia.2019.1130

Copyright: Published by PressAcademia and limited licenced re-use rights only.

\section{ABSTRACT}

Purpose- This study aims to examine the influence of relationship quality and power on value creation and appropriation and ultimately, on satisfaction and relationship continuity. Based on the theory of social exchange, this study proposes a conceptual model, which positions value creation and appropriation as central variables in the nomological network of business relationships.

Methodology- A quantitative study of 174 suppliers was carried out in order to compare the theoretical model with the empirical reality.

Findings- The results obtained show that the relationship quality promotes greater value creation and appropriation in ongoing business relationships. As for power, its influence differs depending on how it is exercised within the relationship. Moreover, the appropriation of value remains the main driver of partner satisfaction, a sine qua non condition for the continuity of the relationship.

Conclusion- This research contributes to a better understanding of value creation-appropriation in ongoing business relationships. By strategically managing their customer-supplier relationships, managers can create and capture greater value and gain a competitive advantage.

Keywords: Value creation, value appropriation, relationship quality, power, relational satisfaction, relationship continuity. JEL Codes: M31, L10

\section{INTRODUCTION}

Managing business relationships continues to be a challenge for many firms, even though they have become increasingly common in contemporary business practices. Inter-firm relationships, seen as a key source of value creation and appropriation, have become the subject of increasing attention from researchers and practitioners. Thus, the notion of "value" is at the core of business relationships and is a critical element in their success. This is reflected in considerable academic literature (Lindgreen and Wynstra 2005; Lindgreen et al., 2012). However, the concept of "value" still suffers from a multitude of competing theoretical perspectives and foundations, creating a certain ambiguity and making it even more difficult to understand (Sandberg et al., 2018; Francis et al., 2014). In addition, the two central issues in value research, namely value creation and value capture, are addressed separately by the authors (Cherni and Leroux, 2015), leaving the interaction between the two concepts relatively ignored (Wanger et al, 2010, Mizik and Jacobson, 2003; Ellegaard et al., 2014).

Over the past two decades, the paradigm shift in marketing to relationships has resulted in increased research on the quality of relationships and the increased importance of satisfied business relationships (Athanassopoulou, 2006). In particular, researchers' attention has focused on relationship quality as a prerequisite for successful business relationships (Athanasopoulou, 2009; Liu et al, 2010). However, the presence of power asymmetry in such relationships can be counterproductive, as it can encourage opportunism or allow excessive appropriation of the value created in the relationship (Nyaga et al., 2013). Several researchers argue that power asymmetry in business relationships is an important area for research, because differences in power between the two partners are generally unavoidable (Nyaga et al., 2013, Brito and Miguel, 2016). 
It is clear from the above discussion that business relationships create value for both dyadic partners. However, this tells us little about how this total value created is shared between the two actors. Some researchers have argued that even if a collaborative or partnership relationship results in the creation of greater value than an arm's length relationship, this does not necessarily mean that the value created will be shared equitably between the two partners (Cox et al., 2004; Chicksand and Rehme, 2018). The literature suggests that companies will seek to capture as much value as possible through the relationship (Mizik and Jacobson, 2003, Crook and Combs, 2007).

Despite the existence of several perspectives, we argue that understanding the power dynamics between customers and suppliers is essential to explain how the total value created is shared in the supply chain. Indeed, the amount of value that each partner manages to capture is a function of their relative power in the relationship, which has further implications in satisfaction and relationship continuity, but that has not been thoroughly explored in the literature (Brito and Miguel, 2016; Crook and Combs, 2007).

As the relationship quality and the use of power affect the relationship experience, and value distribution influences the perception of satisfaction and the expectations of relationship continuity, it is important to investigate the interaction of these concepts.

From there, our research is guided by the following main issue:

To what extent does relationship quality and power influence value creation and appropriation by the dyadic partners and, ultimately, satisfaction and relationship continuity?

More specifically, this research attempts to answer several questions that have been little explored by previous research:

What is the impact of relational variables and power bases on value creation and appropriation?

What is the nature of the links between value creation and value appropriation?

What is the impact of the interaction between value creation and value appropriation on relational satisfaction and relationship continuity?

To shed light on the creation and appropriation of value in business relationships, this paper adopts the following structure: The first section presents the theory of social exchange as a theoretical framework. The second section is devoted to literature analysis and hypothesis development. The research methodology of the empirical study is detailed in the third section, followed by a discussion of the results. Finally, the managerial implications as well as the possibilities for future research are presented in the last section.

\section{THEORETICAL FRAMEWORK: SOCIAL EXCHANGE THEORY}

Social exchange theory (SET) has been widely used by marketers to explain business-to-business relational exchange. Any interaction between actors (individuals or organizations) is an exchange of resources (Homans, 1958). Seminal research that has contributed to the development of SET includes research by sociologists Blau (1955, 1960, 1964), Emerson (1962), Homans (1958) and psychosociologists such as Thibaut and Kelley (1959). Homans (1958), developed the first systematic theory that focuses on social behaviour as an "exchange". However, Blau (1964), may have been the first to use the term "social exchange theory" to describe his conceptualization of "social interaction as an exchange process" (Chadwick-Jones 1976). Thibaut and Kelley (1959) are also often cited as important contributors to SET, because of their concepts of: level of comparison (CL) and level of comparison of alternatives (CLalt), which are used to explain how the parties in the exchange relationship weigh the benefits of the exchange relationship to determine their relational engagement. Emerson's (1962) main contribution to SET is his research on the effects of power and dependence on exchange relationships. He theorizes that power imbalances make relationships unstable and that, therefore, interdependence is crucial to maintaining a social exchange relationship (Lambe et al., 2001).

SET consists of four fundamental premises, namely: (1) exchange interactions result in economic and/or social outcomes; (2) these outcomes are compared over time with other exchange alternatives to determine dependence on the exchange relationship; (3) positive outcomes increase over time companies' trust in their business partners and their commitment to the exchange relationship; and (4) positive exchange interactions over time produce relational exchange standards that govern the exchange relationship.

SET considers exchange as social behaviour that can lead to economic and social outcomes. Organizations form new associations and maintain old ones because they expect a gratification (Homans 1958; Thibaut and Kelley 1959; Blau 1964). Although economic rewards such as money are important, social rewards such as satisfaction are often also valued. Similarly, an exchange relationship involves associated costs. SET suggests that the parties will remain in the relationship as long as satisfactory rewards continue (Homans, 1958; Blau, 1968). Independently of how the two types of results are weighted, 
economic and social results are judged together and compared to certain alternatives (Homans 1958; Thibaut and Kelley 1959; Blau 1964).

In this study, social exchange theory makes it possible to develop hypotheses on the interaction between the creation and appropriation of value and its impact on satisfaction and relationship continuity. The following section presents the conceptual model, and the development of hypotheses.

\section{HYPOTHESIS DEVELOPMENT AND CONCEPTUAL MODEL}

\subsection{Relationship Quality (RQ)}

Interest in developing and maintaining successful business relationships has increased in recent years (Jap, 2001). Indeed, the nature of the relationship between the two partners plays an important role in the success of a long-term exchange relationship, and determines the probability that transactions between the partners will continue (Liu et al., 2010). In particular, it has been proved that relationship quality has a positive impact on performance and relational benefits that flow from it (Athanasopoulou, 2009). Although previous research has discussed and tested the concept in various research contexts, the definition and operationalization of relationship quality differs from one research project to another (Henneberg et al., 2016). Nevertheless, the authors agree that the concept of relationship quality is a multidimensional construct with variable content, a higher order concept consisting of several distinct but related components or dimensions, often operationalized in a monadic way (Henneberg et al., 2016). Thus, relationship quality represents the overall relationship in an abstract way, rather than as specific dimensions of the relationship (e.g., trust or engagement) (Nyaga and Whipple, 2011; Nyaga et al., 2013). Although the literature on the dimensions of RQ has not been unanimous (Athanasopoulou, 2009), researchers agree that trust, commitment and communication are key dimensions of RQ (Liu et al., 2010, Nyaga et al., 2013; Henneberg et al., 2016). Therefore, this study focuses on trust, commitment and communication as key components of RQ.

Trust refers to the extent to which both partners perceive each other as credible and benevolent (Ganesan, 1994; Doney and Cannon, 1997). Trust is the impetus for value creation in exchange relationships (Chen et al., 2017). It has a positive impact on the value generated by the relationship mainly through improved benefits and reduced costs (Wathne and Heide, 2000). Commitment reflects a lasting desire to continue a valuable business relationship, accompanied by a willingness to make the necessary efforts to maintain it (Morgan and Hunt, 1994; Ganesan, 1994). Commitment is an important element of social exchange, as it ensures that partners will make the necessary efforts and investments to produce mutually desirable results (Dwyer et al., 1987, Ganesan, 1994). In this way, commitment promotes successful relationships, increased satisfaction and mutual benefits (Morgan and Hunt, 1994). Finally, communication refers to the formal and informal sharing of useful and relevant information between companies (Anderson and Narus, 1990). It allows both partners to improve their efficiency, responsiveness and flexibility (Abbad, 2008), in order to promote better value creation. Open and frequent communication between the two partners makes it possible to develop a congruence in perceptions and expectations regarding the relationship and also to minimize uncertainty, which will improve exchange and generate more value (Nyaga et al., 2013, Palmatier, 2008). When considered together, the three elements (trust, commitment and communication) clearly reflect the overall relationship quality in customer-supplier exchanges. Consequently, relationship quality is expected to positively influence value creation by the exchange partners. Several previous studies have demonstrated that the emergence of a relationship quality between the two parties provides the appropriate conditions for superior and sustainable value creation (Dyer and Singh, 1998; Kale et al., 2000; Palmatier, 2008; Wagner and Lindemann, 2008; Kang, 2013). Hence the following hypothesis:

\section{H 1: relationship quality is positively associated with value creation.}

\subsection{Coercive Power}

Coercive power is based on the perception of a party, in a business relationship, that the partner has the capacity to punish him if his demands are not met (Lacoste and Blois, 2015). These sanctions may include, for example, imposing financial penalties, suspending significant support, or threatening to withdraw from initial promises (Goodman and Dion, 2001). The exercise of this form of power reflects negative and aggressive behaviour, which essentially forces the other party in the relationship to do things that they would not otherwise have done (Frazier and Rody, 1991).

This involuntary commitment is most likely to lead to dissent, resentment, conflict, dissatisfaction, underperformance and refusal to participate (Benton and Maloni 2005, Jonsson and Zineldin 2003). Indeed, the use of coercive power can be considered as a form of opportunism, because the party who exerts pressure often expects to profit from it to the detriment of the weakest company (Nyaga et al., 2013). This situation is more likely to lead to higher monitoring costs and to intensify disagreements between the two partners (Leonidou et al., 2008, Bandara et al., 2017), thus limiting value creation.

For McDonald (1999), coercive power in a relationship is a serious barrier to effective collaboration. Indeed, the coercive exercise of power hinders the dyad's attempts to establish effective and successful collaborative relationships (Bandara et 
al., 2017). Johnson et al. (1993), argue that coercive use of power leads to a decrease in value creation in the relationship, mainly due to economic sanctions imposed and negative psychological pressure felt (Leonidou et al., 2008). Thus, the use of this source of power will increase perceived costs (both economic and social) to a level that may exceed the respective benefits derived from the relationship and thus reduce value creation (Leonidou et al., 2008; Nyaga et al., 2013). Previous studies have confirmed the negative relationship between coercive power and dyad outcomes, including cooperative relationships (Ferrer et al., 2010), adaptive and collaborative behaviours (Nyaga et al., 2013) and relationship success (Bandara et al., 2017). Therefore, we assume the following:

\section{H 2: Coercive power is negatively associated with value creation.}

\subsection{Non-coercive Power}

Reciprocally to coercive power, non-coercive power does not include aggressive or competitive actions that will produce friction in the relationship. On the contrary, it actively inspires the interacting parties to work together for their common interests. As a result, conflict in the relationship will be reduced, while any form of disagreement will be functional rather than dysfunctional. Indeed, the use of non-coercive power helps to increase financial and social benefits, for example by providing financial rewards, assistance and/or access to specialized information (Wilkinson, 1979). All these elements will contribute to promoting shared objectives and common interests (Leonidou et al., 2008), thus contributing to the creation of greater value. Gelderman et al. (2008) note that non-coercive strategies are intended to change the partner's attitude and that these strategies have a positive impact on the relationship. As Belaya et al. argues, (2009), non-coercive power can be used as "an effective tool to coordinate and promote harmonious relationships, resolve conflicts and, consequently, improve the performance of the entire supply chain network". In other words, non-coercive power is an impetus for teamwork, improved supply chain relationships and superior performance (Arend and Wisner, 2005). In this perspective, the sources of non-coercive power tend to increase the value generated by the relationship for both members by increasing the level of cooperation (Jonsson and Zineldin, 2003). Many previous studies have shown that when power is not abused or coercively used, there is an overall improvement in relationships (Crook and Combs, 2007; Frazier and Summers, 1986; Jonsson and Zineldin, 2003; Maloni and Benton, 2000; 2005; Nyaga et al., 2013; Bendara et al., 2017). Hence the following is hypothesized:

H 3: Non-coercive power is positively associated with value creation.

\subsection{Value Creation and Value Appropriation}

The creation of value and the maximization of its ownership have long been recognized as the main goals of organizations (Anderson, 1995) and the source of competitive advantage (Coff, 1999). From a conceptual point of view, value creation and value appropriation represent two sides of the same coin. Value creation involves the total net value (i.e. total benefits minus total sacrifices) created as part of a business relationship between the two exchange partners. Value appropriation represents the net value that a member of the dyad successfully claims (Wagner et al., 2010).

From the perspective of institutional arrangements, companies that engage in value-creating institutional relationships do so only with the objective of capturing a portion of the value created, so that maximizing value creation must be aligned with maximizing its appropriation for each of the participating companies. Indeed, value creation and value appropriation represent two closely linked perspectives of value. Value creation is a prerequisite for value appropriation, while value appropriation is the purpose of value creation (Zhao et al, 2014; Carson et al., 1999). According to Wagner et al (2010), value creation improves value appropriation for both members of the relationship. The more successful the relationship is in terms of value creation, the more value each company can claim (win-win situation). Thus, by increasing the total value created in a relationship, the value captured by each party can increase (Miguel et al., 2014; Tescari and Brito, 2016; Yan and Wagner, 2017; Fang et al., 2008). Therefore, we assume the following hypothesis:

\section{H 4: Value creation is positively associated with value appropriation.}

\subsection{Value Appropriation, Relational Satisfaction and Relationship Continuity}

The current literature on supply chain management assumes that mutually beneficial relationships lead to partner satisfaction (Meloni and Benton, 2005), as well as stability and continuity of the relationship. Satisfaction is an important factor in building long-term relationships and plays a key role in determining their future. Similarly, without satisfaction, both partners are unable to generate the psychological factors and goodwill necessary to maintain the relationship (Meloni and Benton, 2005).

Value appropriation can have direct and indirect effects on relationship continuity. The indirect impact is simple: value appropriation has a positive impact on partner satisfaction, which promotes stability and continuity of the relationship. Indeed, the greater the value that a company can obtain from a relationship, the more likely the perceived outcomes are considered to be above previous expectations $(\mathrm{CL})$ and the fewer better alternatives are available on the market (CLalt), which results in more satisfaction with the current relationship (Thibaut and Kelley 1959). According to Kumar et al, (1995), a 
significant portion of the value for dyad members increases satisfaction with the relationship. The same conclusion was supported by Deligonul et al (2006) and Wagner and Lindemann (2008).

Moreover, relational satisfaction is a sign of relationship continuity of the in time. Its degradation makes the relationship difficult to manage and questions its maintenance and longevity (Meloni and Benton, 2005). In fact, satisfaction is widely accepted by researchers as a strong predictor for behavioral outcomes such as intentions to pursue and develop the relationship. Thus, the academic literature attests that satisfaction increases cooperation between partners, reduces conflict as well as propensity to leave the relationship (Ulaga and Eggert, 2006). Partners' satisfaction with the results achieved influences the future of the relationship. Because current experiences are expected to reoccur in future relationships, companies will only continue their relationships if their current results meet their expectations (Wagner et al., 2010). Therefore, we make the following two assumptions:

\section{H 5: Value appropriation is positively associated with relational satisfaction.}

H 6: Relational satisfaction is positively associated with relationship continuity.

The basic assumptions of social exchange theory suggest the direct effect of value appropriation on partners' intentions to pursue the relationship. Indeed, at the business relationship level, inter-firm interactions are often based on expected rewards (Blau, 1964; Emerson, 1976). Thus, companies estimate the expected value of a relationship and, on this basis, adjust their behavior and actions towards their partner and the relationship. If the perceived value is greater than or equal to expectations, companies are motivated to engage in new transactions and allocate more effort and resources to continue the relationship. Conversely, if results are below expectations, partners may leave the relationship (Griffith et al., 2006, Nyaga et al., 2013). In other words, the higher the value expected or received from a business relationship, the greater the partners' motivation to continue the exchange process (Ulaga and Eggert, 2006), therefore, we hypothesize that:

\section{H 7: value appropriation is positively associated with relationship continuity.}

This study also argues that relational satisfaction mediates the relation between value appropriation and intentions of relationship continuity. According to the theory of reasoned action, cognitive variables are mediated by affective variables to produce connotative results (Fishbein and Ajzen, 1977). Ulaga and Eggert (2006), in their research, empirically tested how cognitive perceptions of the value derived from the relationship interact with affective feelings of satisfaction, ultimately leading to behavioural intentions to maintain and intensify a business relationship. According to these authors, value appropriation has a direct impact on the partners' intention to pursue and develop their relationship, as well as an indirect impact that is mediated by the construction of relational satisfaction. Hence the following hypothesis:

H 8: Relational satisfaction mediates the relationship between value appropriation and relationship continuity.

Figure 1: Illustrates the Conceptual Model and Proposed Assumptions

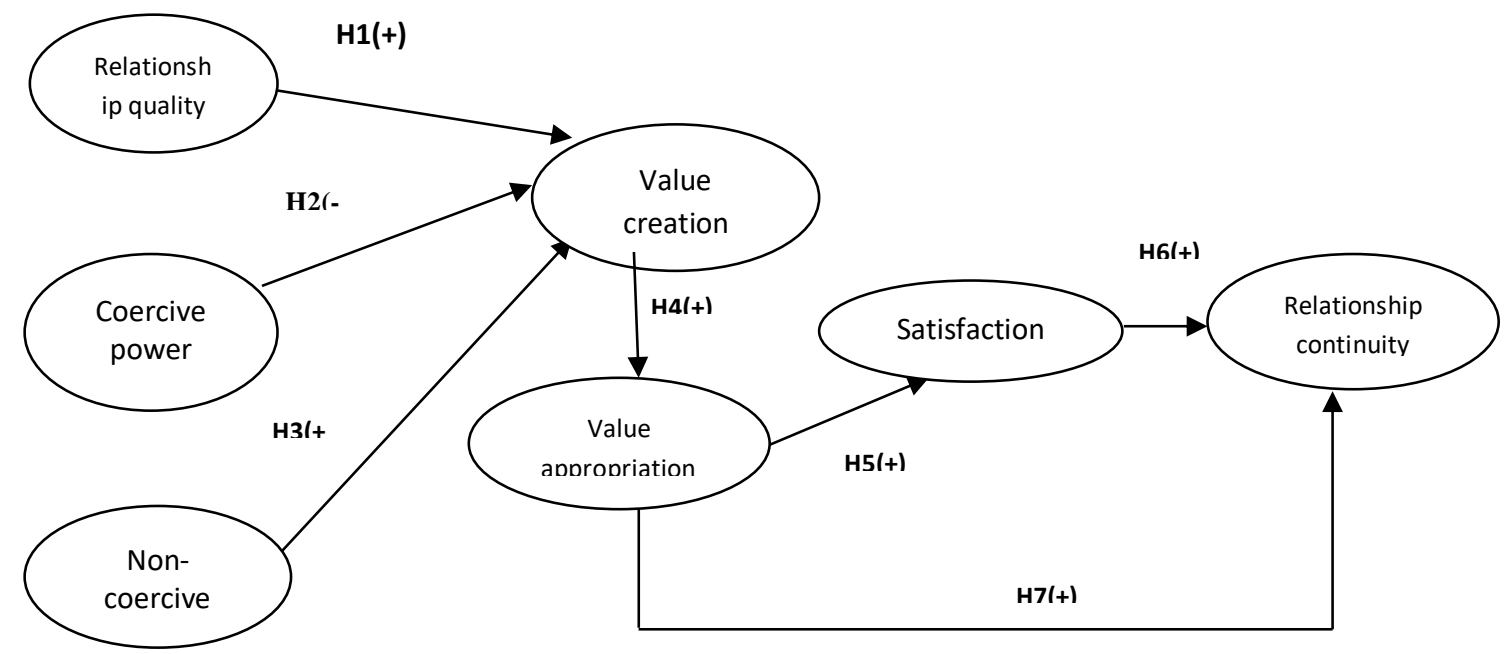

\section{METHODOLOGY}

The data were collected from a sample of Moroccan suppliers (operating in various sectors) through an online survey. Indeed, this study focuses on the supplier perspective because customers are generally more powerful partners in the relationship (for several reasons related to size, dependence and intensity of competition). The sampling frame included about 1000 
companies operating in business markets in Morocco. It contained e-mail addresses as well as telephone numbers. Respondents were contacted mainly by email, containing a personalized link to the questionnaire. A total of 178 responses were received, representing a response rate of $17.8 \%$. After verification, 174 responses were found to be valid and complete. Respondents held positions of responsibility in their companies. The majority of them were senior managers with a global vision of the supply chain, as well as a perfect knowledge of their company's customers' activities and customer relationships. These target persons were mainly directors in the case of a small or medium-sized company, or commercial or logistics managers in the case of a large company. Respondents were asked to consider a unique relationship in which they were directly involved. The instructions explained that questions should be answered with reference to the main customer.

Non-response bias was estimated by comparing early and late respondents. For all model items examined, there was no statistically significant difference (Armstrong and Overton, 1977).

To measure the theoretical constructs of our model, we have adopted measurement scales already used in previous studies. These have been adapted to suit the research context. In addition, since all the measurement scales are based on AngloSaxon research, it was necessary to translate them. We carried out this translation, using the technique of "back translation". The translation was from English into French, which remains the language used by companies and their executives in the Moroccan professional context. We used a five-step Likert scale, as it is easier to use and shorter to answer.

We have operationalized relationship quality as a second-order construct, composed of trust, commitment and communication as first-order factors. The trust measure was based on the items developed by Doney and Cannon's (1997). The commitment scale is based on the items developed by Morgan and Hunt, (1994). The measure of communication used six items developed by Krause and Ellram (1997).

With regard to power (both coercive and non-coercive), this study adopts the measurement items developed by Leonidou et al (2008).

To measure value creation and value appropriation, we adopted the measure elaborated by Wagner et al. (2010) and based on the global measurement of equity (Scheer et al., 2003). The measure of relational satisfaction used the items developed by Crosby et al (1990), while the items developed by Kumar et al (1995) were used to measure intentions of relationship continuity ((see appendix 1$)$.

\section{ANALYSIS AND RESULTS}

Data analysis was based on the structural equation modelling method under the PLS approach (Partial Least Squares) using SMART PLS 3 software (Ringle, Wende and Becker, 2015). This approach maximizes the variance explained by the independent variables of the dependent variables. It differs from structural equation modelling based on covariance and maximum likelihood (CB-SEM), which seeks to reproduce the theoretical matrix of covariances (Hair et al., 2017). In addition, the PLS approach is particularly appropriate for exploratory and predictive studies, in which the researcher seeks to estimate a complex model through a relatively small sample (Hair et al., 2017), as was the case for this study. It is also less demanding in its conditions of use (no data normality, few probabilistic assumptions at the outset) and allows for simple and direct data modelling (Sosik et al., 2009; Lacroux, 2009).

This study followed standard evaluation guidelines for reporting PLS-SEM results (Hair et al., 2017). The analysis involved a two-step approach: 1) validate the measurement model (or external model) and 2) estimate the structural model (or internal model) (Hair et al., 2017).

\subsection{Analysis of Reflective Measurement Models}

First, we purified our data using the SPSS software by performing an exploratory factor analysis (EFA) for each of our latent variables to ensure their unidimensionality. Purification was done by eliminating items with factor contributions of less than 0.5 on the main components (Chandon, 2007). Secondly, it was necessary to ensure the reliability of the constructs, through the Cronbach alpha test, which must be greater than 0.6 (Nunnally, 1978). In order to evaluate the measurement model in PLS-SEM, we used several indices: individual indicator reliability, construct reliability, convergent validity and discriminant validity.

The reliability of each indicator depends on examining the standardized factor loadings. Reliability is considered acceptable when an indicator has a standardized factor loading of $\geq 0.70$ on its respective construct (Fornell \& Larcker, 1981). Table 1 shows the standardized factor loadings for all first-order reflective constructs. 
Table 1: Measurement Model Results

\begin{tabular}{|c|c|c|c|c|}
\hline Construct name / items & Factor loading & Cronbach Alpha & $\begin{array}{l}\text { Composite } \\
\text { reliability }\end{array}$ & AVE \\
\hline $\begin{array}{l}\text { Trust } \\
\text { TRUST1 } \\
\text { TRUST2 } \\
\text { TRUST3 } \\
\text { TRUST4 } \\
\text { TRUST5 } \\
\text { TRUST6 } \\
\text { TRUST7 }\end{array}$ & $\begin{array}{l}0.793 \\
0.725 \\
0.765 \\
0.728 \\
0.803 \\
0.794 \\
0.791\end{array}$ & 0.887 & 0.912 & 0.596 \\
\hline $\begin{array}{l}\text { Commitment } \\
\text { COMMIT1 } \\
\text { COMMIT2 } \\
\text { COMMIT3 } \\
\text { COMMIT4 } \\
\text { COMMIT6 }\end{array}$ & $\begin{array}{l}0.828 \\
0.857 \\
0.868 \\
0.756 \\
0.838\end{array}$ & 0.886 & 0.917 & 0.689 \\
\hline $\begin{array}{l}\text { Communication } \\
\text { COMM2 } \\
\text { COMM3 } \\
\text { COMM4 } \\
\text { COMM5 } \\
\text { COMM6 }\end{array}$ & $\begin{array}{l}0.700 \\
0.770 \\
0.875 \\
0.799 \\
0.883 \\
\end{array}$ & 0.865 & 0.903 & 0.653 \\
\hline $\begin{array}{l}\text { Relationship quality } \\
\text { TRUST } \\
\text { COMMITMENT } \\
\text { COMMUNICATION }\end{array}$ & $\begin{array}{l}0.846 \\
0.868 \\
0.859\end{array}$ & - & 0.893 & 0.857 \\
\hline $\begin{array}{l}\text { Coercive power } \\
\text { CPW1 } \\
\text { CPW2 } \\
\text { CPW3 } \\
\text { CPW4 } \\
\text { CPW5 }\end{array}$ & $\begin{array}{l}0.788 \\
0.888 \\
0.815 \\
0.761 \\
0.778 \\
\end{array}$ & 0.867 & 0.903 & 0.652 \\
\hline $\begin{array}{l}\text { Non-coercive power } \\
\text { NCPW1 } \\
\text { NCPW3 } \\
\text { NCPW4 }\end{array}$ & $\begin{array}{l}0.780 \\
0.829 \\
0.808\end{array}$ & 0.739 & 0.848 & 0.650 \\
\hline $\begin{array}{l}\text { Value creation } \\
\text { VALUE1 } \\
\text { VALUE2 }\end{array}$ & $\begin{array}{l}0.975 \\
0.975\end{array}$ & 0.948 & 0.975 & 0.950 \\
\hline $\begin{array}{l}\text { Value appropriation } \\
\text { VAL SUPL1 } \\
\text { VAL SUPL2 }\end{array}$ & $\begin{array}{l}0.959 \\
0.961\end{array}$ & 0.915 & 0.959 & 0.921 \\
\hline $\begin{array}{l}\text { Satisfaction } \\
\text { SATISFAC1 } \\
\text { SATISFAC2 } \\
\text { SATISFAC3 }\end{array}$ & $\begin{array}{l}0.898 \\
0.951 \\
0.921\end{array}$ & 0.914 & 0.946 & 0.853 \\
\hline $\begin{array}{l}\text { Relationship continuity } \\
\text { CONTIN1 } \\
\text { CONTIN2 } \\
\text { CONTIN3 }\end{array}$ & $\begin{array}{l}0.878 \\
0.849 \\
0.856\end{array}$ & 0.826 & 0.896 & 0.741 \\
\hline
\end{tabular}

Second, the reliability of all reflective constructs was assessed by analyzing two types of indicators: Cronbach's alpha, and composite reliability. The recommended value is $\geq 0.70$ for all two types of reliability. The values of Cronbach's alpha, and composite reliability exceeded 0.70 , confirming the convergence or internal consistency of all first-order constructs(Table 1 ) 
Third, convergent validity is assessed through the average variance extracted (AVE) which must have a value $\geq 0.5$ to demonstrate that it is able to explain more than half of the variance of these indicators. In accordance with this recommendation, all variables had AVE values greater than 0.5 (see table 1 ).

Fourth, we assessed discriminating validity through two approaches: Cross-loading and correlations between constructs (Fornell and Larcker criterion). For the first approach, the factor loadings of all items attached to a construct must be greater than their cross-loadings (i.e., their correlation) with other constructs (see appendix 2). As per the Fornell and Larcker (1981) criterion, the variance shared by a construct with its indicators, measured by the square root of the AVE, must be greater than the variance shared between latent constructs, measured by the correlations between constructs (see table 2 ). The results obtained confirm the discriminating validity of all our variables.

Table 2. Discriminant validity

\begin{tabular}{|c|c|c|c|c|c|c|c|c|c|c|}
\hline & $\begin{array}{c}\text { Value } \\
\text { appropriation }\end{array}$ & $\begin{array}{c}\text { Communi } \\
\text { cation }\end{array}$ & Trust & $\begin{array}{l}\text { Relationship } \\
\text { continuity }\end{array}$ & $\begin{array}{c}\text { Value } \\
\text { creation }\end{array}$ & $\begin{array}{l}\text { Commi } \\
\text { tment }\end{array}$ & $\begin{array}{c}\text { Coercive } \\
\text { power }\end{array}$ & $\begin{array}{c}\text { Non- } \\
\text { coercive } \\
\text { power }\end{array}$ & $\begin{array}{l}\text { Satisfa } \\
\text { ction }\end{array}$ & $\mathbf{R Q}$ \\
\hline $\begin{array}{l}\text { Value } \\
\text { appropriation }\end{array}$ & 0.960 & & & & & & & & & \\
\hline Communication & 0.312 & 0.808 & & & & & & & & \\
\hline Trust & 0.363 & 0.560 & 0.772 & & & & & & & \\
\hline $\begin{array}{l}\text { Relationship } \\
\text { continuity }\end{array}$ & 0.447 & 0.375 & 0.377 & 0.860 & & & & & & \\
\hline Value creation & 0.866 & 0.329 & 0.394 & 0.511 & 0.975 & & & & & \\
\hline Commitment & 0.264 & 0.695 & 0.561 & 0.499 & 0.322 & 0.830 & & & & \\
\hline Coercive power & -0.252 & -0.139 & -0.326 & -0.363 & -0.313 & -0.149 & 0.808 & & & \\
\hline $\begin{array}{l}\text { Non-coercive } \\
\text { power }\end{array}$ & 0.209 & 0.112 & 0.197 & 0.164 & 0.235 & 0.103 & 0.043 & 0.808 & & \\
\hline Satisfaction & 0.504 & 0.367 & 0.543 & 0.568 & 0.514 & 0.396 & -0.302 & 0.297 & 0.924 & \\
\hline $\begin{array}{l}\text { Relationship } \\
\text { quality }\end{array}$ & 0.368 & 0.861 & 0.845 & 0.485 & 0.410 & 0.868 & -0.248 & 0.164 & 0.516 & 0.926 \\
\hline
\end{tabular}

\section{a. Evaluation of the Second Order Variable}

To confirm that relationship quality is a higher-order construct, with a second-order factor represented reflectively by three first-order factors, an exploratory factorial analysis using Principal Axis Factoring with an oblique rotation (direct Oblimin) was first performed. Relationship quality was found to be a higher order latent variable represented by three dimensions, in line with the conceptualization adopted and recommended in the literature. 17 of the 19 items had loadings above the minimum threshold (0.5) within each dimension. Also, each of the three first-order factors had Cronbach values above the recommended lower limit of 0.6 (Nunnally \& Bernstein, 1994) (see Table 1).

Repeated Measures Approach: For PLS-SEM, the validity of higher-order latent constructs (known as hierarchical component models) can be assessed using the repeated measurement approach. First, all indicators are assigned to their respective dimensions reflectively. Then, all indicators are reassigned a second time to the second-order construct reflectively. Finally, the relationship between the second-order construct and its dimensions is specified as reflexive (Hair et al., 2014; 2018; Becker et al., 2012).

The assessment of the reliability and convergent validity of the scale of the latent variable "relationship quality" will follow the following steps: First, and for each of the three dimensions, we will evaluate the factor loadings of the indicators, the average variance extracted (AVE), the composite reliability (CR), the Cronbach alpha index ( $\alpha$ ) and the discriminant validity. Then, once we have ensured validity and reliability of each dimension, we will proceed to estimate the psychometric quality of our second-order variable using the same criteria (validity and reliability). Finally, to demonstrate the relevance and fit of the relationship quality measurement model, we must establish that the relationships between the second-order construct and its dimensions are strong and significant $(p<0.05)$ and the coefficient of determination $\left(R^{2}\right)$ of each dimension is greater than 0.5 , indicating that the second-order variable explains more than $50 \%$ of the variance in its dimensions (Hair et al, 2014).

Examination of the various tests revealed that all conditions required to ensure the reliability as well as the convergent and discriminating validity of the latent variable relationship quality and its three dimensions are met (see table 1 and appendix 2). As shown in the table above, the relationships between the second-order construct of relationship quality and its dimensions are all strong and significant. Similarly, all $R^{2}$ values are greater than 0.5 . Therefore, the results of the confirmatory factor analysis and the significance of the path coefficients support relationship quality as a higher order latent construct represented reflectively by three dimensions (Trust, Commitment and Communication). 
Table 3: Assessment of the Relationship Quality Measurement Model

\begin{tabular}{|l|c|c|c|c|c|}
\hline & $\begin{array}{c}\text { Original } \\
\text { Sample }\end{array}$ & Sample Mean & $\begin{array}{c}\text { Standard } \\
\text { Deviation }\end{array}$ & T Statistics & $\mathbf{R}^{\mathbf{2}}$ \\
\hline Relationship quality -> Trust & 0.846 & 0.846 & 0.025 & 33.884 & 0.715 \\
\hline $\begin{array}{l}\text { Relationship quality -> } \\
\text { Commitment }\end{array}$ & 0.868 & 0.868 & 0.024 & 35.621 & 0.753 \\
\hline $\begin{array}{l}\text { Relationship quality -> } \\
\text { Communication }\end{array}$ & 0.859 & 0.859 & 0.027 & 32.124 & 0.739 \\
\hline
\end{tabular}

\subsection{Evaluation of the Structural Model}

This study applies the standard guidelines in Hair et al (2017) for the evaluation of the structural model. First, the structural model was checked for collinearity between the variables. To do this, we examined the variance inflation factor (VIF) value for all independent constructs.

Table 4: Estimation of the Collinearity between Structural Model Constructs

\begin{tabular}{|l|c|c|c|c|}
\hline & Value appropriation & Relationship continuity & Value creation & Satisfaction \\
\hline Value appropriation & & & & 1.000 \\
\hline Relationship continuity & & & & \\
\hline Value creation & 1.334 & & & \\
\hline Coercive power & 1.154 & 1.143 & 1.077 & \\
\hline Non-coercive power & 1.085 & 1.124 & 1.036 & \\
\hline Relationship quality & 1.241 & 1.385 & 1.107 & \\
\hline Satisfaction & & 1.547 & & \\
\hline
\end{tabular}

As shown in the table 4, all VIF values are below the critical threshold of 5 (Hair et al., 2017), confirming that colinearity between structural model variables is not a critical issue for the rest of the analysis.

Then, the structural model was evaluated using the coefficients of determination $\left(R^{2}\right)$ and the cross-validated redundancy coefficients $\left(Q^{2}\right)$ to assess the predictive relevance of its latent variables,(i.e. their nomological validity). According to Hair et al., 2017, the coefficients of determination $\left(R^{2}\right)$ must be greater than 0.25 for the model to be significant. The table 5 shows that all the coefficients of determination $\left(R^{2}\right)$ have a value greater than 0.25 , which proves that the structural model has a satisfactory predictive power in the sample (Hair et al., 2014; 2017). This result is also supported by the redundancy coefficients values $\left(Q^{2}\right)$. Indeed, all $Q^{2}$ values are significantly greater than zero, which confirms the predictive relevance of the model in terms of out-of-sample prediction (Hair et al., 2014; 2017).

Table 5: Predictive Validity of the Structural Model

\begin{tabular}{|l|c|c|c|}
\hline Variable & $\mathbf{R}^{\mathbf{2}}$ & Signification & $\mathbf{Q}^{\mathbf{2}}$ \\
\hline Value appropriation & 0.751 & Elevée & 0.645 \\
\hline Relationship continuity & 0.404 & Modérée & 0.263 \\
\hline Value creation & 0.251 & Faible & 0.227 \\
\hline Satisfaction & 0.254 & Faible & 0.200 \\
\hline
\end{tabular}

Next, the sizes and significance of the path coefficients that reflect the hypotheses were examined. The significance of the path coefficients was calculated using the bootstrapping procedure (with 5000 bootstrap samples and 174 bootstrap cases). 
Figure 2: Results of Structural Model

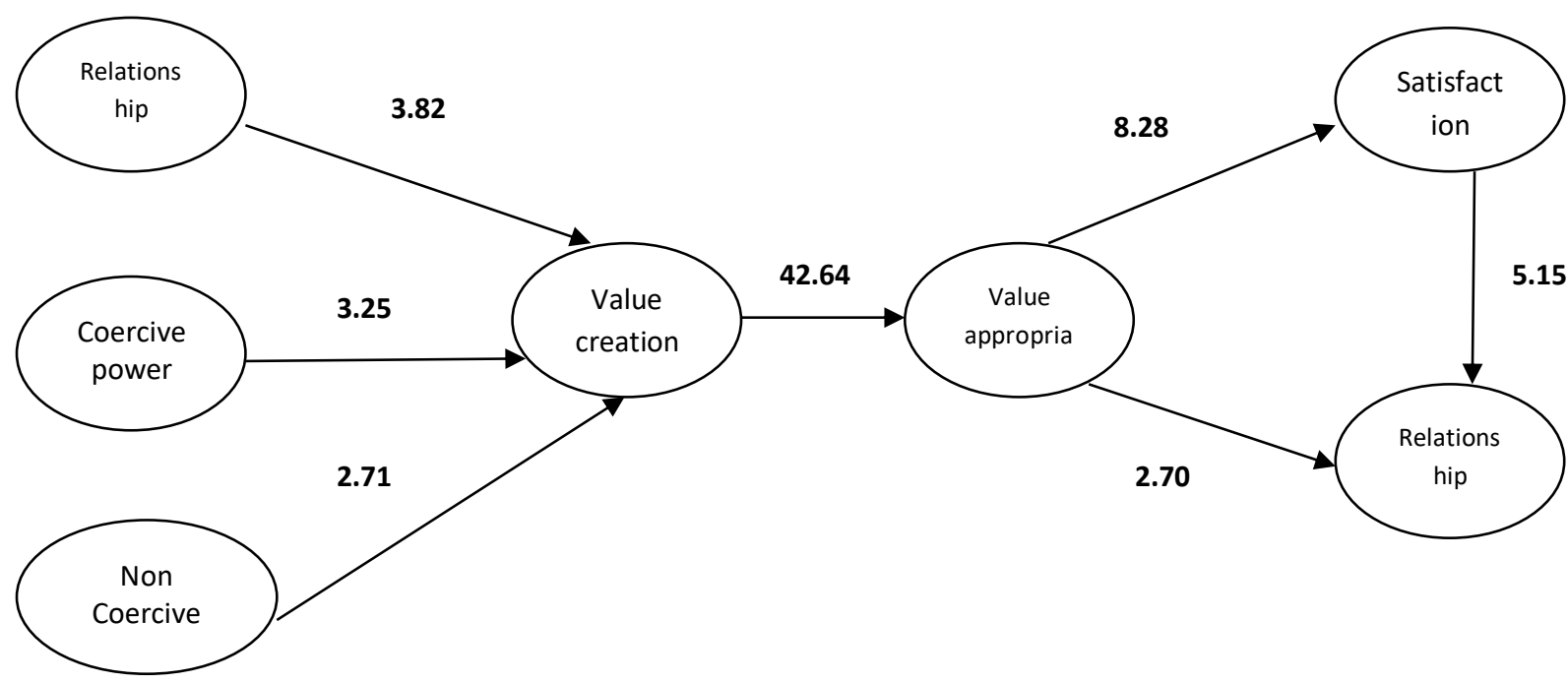

In addition to assessing the importance and significance of the structural path coefficients obtained, the magnitude of the effects size $f^{2}$ and $q^{2}$ should also be examined.

The effect size $f^{2}$ allows assessing an exogenous construct's contribution to an endogenous latent variable's $\mathrm{R}^{2}$ value. For its part, the effect size $q^{2}$ makes it possible to assess the contribution of an exogenous latent variable to the prediction of an endogenous latent variable. Its two indicators should be $\geq 0.02$ (Hair et al.,2017).

The table 6 summarizes hypothesis testing results as well as $f^{2}$ and $q^{2}$ values.

Table 6: Estimation Result of the Structural Model

\begin{tabular}{|c|c|c|c|c|c|c|c|c|c|c|c|}
\hline \multirow{2}{*}{$\begin{array}{l}\text { Hypot } \\
\text { hesis }\end{array}$} & \multirow{2}{*}{$\begin{array}{l}\text { Structural } \\
\text { relationship }\end{array}$} & \multirow{2}{*}{$\begin{array}{l}\text { Original } \\
\text { Sample }\end{array}$} & \multirow{2}{*}{$\begin{array}{l}\text { Sample } \\
\text { Mean }\end{array}$} & \multirow{2}{*}{$\begin{array}{l}\text { Standard } \\
\text { Deviation }\end{array}$} & \multirow{2}{*}{ T Statistics } & \multirow{2}{*}{ P Values } & \multirow{2}{*}{ Decision } & \multicolumn{2}{|c|}{$\begin{array}{l}\text { 95\% confidence } \\
\text { intervals }\end{array}$} & \multirow{2}{*}{$f^{2}$} & \multirow{2}{*}{$q^{2}$} \\
\hline & & & & & & & & $\begin{array}{l}\text { Lower } \\
\text { bound }\end{array}$ & $\begin{array}{l}\text { Upper } \\
\text { bound }\end{array}$ & & \\
\hline H1 & $\begin{array}{l}\text { Relationship } \\
\text { quality -> Value } \\
\text { creation }\end{array}$ & 0.318 & 0.313 & 0.085 & $3.759 *$ & 0.000 & Supported & 0.177 & 0.456 & 0.123 & 0,105 \\
\hline H2 & $\begin{array}{l}\text { Coercive power -> } \\
\text { Value creation }\end{array}$ & -0.243 & -0.248 & 0.077 & $3.159 *$ & 0.001 & Supported & -0.368 & -0.117 & 0.073 & 0,060 \\
\hline H3 & $\begin{array}{l}\text { Non-coercive } \\
\text { power -> Value } \\
\text { creation }\end{array}$ & 0.193 & 0.202 & 0.071 & $2.740 *$ & 0.003 & Supported & 0.086 & 0.313 & 0.048 & 0,038 \\
\hline H4 & $\begin{array}{l}\text { Value creation -> } \\
\text { Value } \\
\text { appropriation }\end{array}$ & 0.866 & 0.866 & 0.020 & $42.557^{*}$ & 0.000 & Supported & 0.832 & 0.898 & 3.003 & - \\
\hline H5 & $\begin{array}{l}\text { Value } \\
\text { appropriation -> } \\
\text { Satisfaction }\end{array}$ & 0.504 & 0.506 & 0.062 & $8.130 *$ & 0.000 & Supported & 0.400 & 0.603 & 0.340 & - \\
\hline H6 & $\begin{array}{l}\text { Satisfaction -> } \\
\text { Relationship } \\
\text { continuity }\end{array}$ & 0.460 & 0.466 & 0.089 & $5.184 *$ & 0.000 & Supported & 0.316 & 0.611 & 0.246 & 0.134 \\
\hline H7 & $\begin{array}{l}\text { Value } \\
\text { appropriation -> } \\
\text { Relationship } \\
\text { continuity }\end{array}$ & 0.215 & 0.212 & 0.079 & $2.724 *$ & 0.003 & Supported & 0.084 & 0.343 & 0.054 & 0,022 \\
\hline
\end{tabular}

*: Significant at the $1 \%$ level (one-sided test). 
Analysis of the path coefficients and levels of significance shows that all hypothesized direct relationships were empirically supported. The empirical results show that relationship quality as well as non-coercive power were positively and significantly related to value creation, supporting $\mathrm{H} 1$ and $\mathrm{H} 3$ (table 6). Moreover, and as assumed, the relationship between coercive power and value creation was negative and significant, also supporting $\mathrm{H} 2$. Empirical results also show direct, significant and positive relationships between value creation and value appropriation, value appropriation and relational satisfaction, value appropriation and relationship continuity, as well as relational satisfaction and relationship continuity. Therefore, assumptions $\mathrm{H} 4, \mathrm{H} 5, \mathrm{H} 6$ and $\mathrm{H} 7$ are supported.

In addition, analysis of the effects size $f^{2}$ and $q^{2}$ for all significant structural relationships in the internal model reveals values greater than 0.02, suggesting satisfactory effects and acceptable predictive relevance for endogenous latent variables (Hair et al., 2017).

Mediation test- To test mediation, we adopted the two-step procedure developed by Zhao et al, (2011), and recommended by Hair et al, (2017) as part of the PLS approach. The first step concerns the significance of the indirect effect via the mediator variable. If the indirect effect is significant, we can conclude that there is a form of mediation. In order to determine its nature, the significance of the direct effect must be assessed (step 2). The results indicate that value appropriation indirectly influences relationship continuity through relational satisfaction ( $\mathrm{H} 8$ is supported). As the direct effect was also significant, the results reveal that relational satisfaction partially mediates (indirect-only mediation) the relationship between value appropriation and relationship continuity (see table 6). To further support the type of partial mediation, we calculated the product of effects (direct and indirect). Since both the direct and indirect effects were positive, the sign of their product is also positive. Therefore, we conclude that this is a complementary mediation.

Table 7: Estimation Results of the Indirect Effect

\begin{tabular}{|c|c|c|c|c|c|c|c|c|c|}
\hline \multirow{2}{*}{$\begin{array}{l}\text { Hypot } \\
\text { hesis }\end{array}$} & \multirow{2}{*}{ Structural relationship } & \multirow{2}{*}{$\begin{array}{l}\text { Original } \\
\text { Sample }\end{array}$} & \multirow{2}{*}{$\begin{array}{c}\text { Sample } \\
\text { Mean }\end{array}$} & \multirow{2}{*}{$\begin{array}{l}\text { Standard } \\
\text { Deviation }\end{array}$} & \multirow{2}{*}{ T Statistics } & \multirow{2}{*}{$P$ Values } & \multirow{2}{*}{ Decision } & \multicolumn{2}{|c|}{$\begin{array}{l}95 \% \text { confidence } \\
\text { intervals }\end{array}$} \\
\hline & & & & & & & & $\begin{array}{l}\text { Lower } \\
\text { bound }\end{array}$ & $\begin{array}{l}\text { Upper } \\
\text { bound }\end{array}$ \\
\hline H8 & $\begin{array}{l}\text { Value appropriation -> } \\
\text { Satisfaction -> Relationship } \\
\text { continuity }\end{array}$ & 0.232 & 0.235 & 0.051 & $4.512^{*}$ & 0.000 & Supported & 0.155 & 0.324 \\
\hline
\end{tabular}

*: Significant at the $1 \%$ level (one-sided test).

\section{CONCLUSION}

This research responds to the need to study the conditions as well as the way in which business relationships between customers and suppliers can contribute to the creation and appropriation of superior and sustainable value. First, this study confirms the positive effect of relationship quality on value creation. This finding is consistent with previous studies that indicate that relationship quality generally leads to positive outcomes (Wagner and Lindemann, 2008; Wagner et al., 2010; Alejandro et al., 2011; Chen et al., 2017). Indeed, the main objective of partners in a business relationship is to work together to create greater value, either by increasing benefits or reducing costs (Walter et al., 2003; Ulaga and Eggert, 2006). However, to create greater value, the members of the dyad must align and consult each other in a meaningful way, which is possible thanks to a high level of relationship quality. Indeed, relationship quality has been suggested by researchers as a fundamental condition for the stability of the business relationship and the creation of sustainable value (Dyer and Chu 2011; Chen et al., 2017). In addition, a stronger and quality relationship increases the parties' positive perceptions of its viability and success, which increases their motivation to make the necessary efforts to create more value (Wagner and Lindemann, 2008). This finding is in line with the strong willingness of companies to invest in quality relationships (Kumar et al., 1995).

Consistent with the findings of previous studies (Johnson et al., 1993, Gulati and Sytch, 2007, Leonido et al., 2008; Hausman and Johnston, 2010), which state that coercive power is generally destructive to business relationships, the results of this study show that in the Moroccan context, coercive power is negatively linked to value creation as perceived by suppliers. Indeed, the use of coercion can create a sense of exploitation in the target, which can lead to conflict (Johnson et al., 1990), dissatisfaction (Skinner et al., 1992), and therefore harming the future development of the relationship (Skinner et al., 1992; Liu et al., 2010). Such a situation would lead the exploited party to seek short-term benefits, creating opposing forces or conflicting goals in the collaborative process, further reducing relationship value (Billitteri et al., 2013, Chen et al., 2017).

The results of this study also confirm the positive effect of non-coercive power on value creation. Indeed, the use of noncoercive power contributes more to increasing value generated by the relationship for both partners, through improved benefits, reduced costs, strengthened relationships and better performance (Jonsson and Zineldin, 2003; Crook and Combs, 2007; Leonidou et al., 2008, Bendara et al., 2017). 
The estimation of path coefficients supports the expected positive effect of value creation on value appropriation. This empirical evidence is consistent with the results of several studies, including those of Wagner et al., (2010), Zhao et al., (2014), Tescari and Brito, (2016) and Yan and Wagner, (2017) which argue that value creation is a prerequisite and indispensable for value appropriation: the greater the value created, the greater the share captured by the participants in the relationship. Value appropriation, in turn, is positively associated with both supplier satisfaction and their willingness to maintain the relationship. This result confirms the importance of value appropriation in the context of business relationships.

Indeed, suppliers' satisfaction with their main customer, as well as their intentions to pursue the relationship, are mainly affected by the value appropriation process. Any dysfunctional act in this process can lead to partner dissatisfaction, relationship instability or, at least, tensions even in the longest and most successful relationships (Ulaga and Eggert, 2006; Deligonul et al., 2006; Wagner et al., 2010).

The last relationship tested was the one that assumed a positive influence of relational satisfaction on relationship continuity. The hypothesis test revealed a significant influence, in accordance with the results of previous studies, for which relational satisfaction is an important factor in the establishment of long-term relationships and plays a key role in their continuity (Ulaga and Eggert, 2006, Meloni and Benton, 2005). Moreover, relational satisfaction was found to mediate partially the association between value appropriation and relationship continuity. Thus, the value derived from the relationship has a direct impact on the partners' intention to continue and develop their relationship, as well as an indirect impact that is mediated by the construction of relational satisfaction (Ulaga and Eggert, 2006).

Future studies can replicate and extend our conceptual model to explore other possible explanations for our results.

Value creation and value appropriation represent the reason for business relationships. However, empirical research on the interaction between these two concepts remains relatively rare. In the context of social exchange theory, this study contributes to a better understanding of the interaction between value creation and value appropriation and its impact on attitude and behavioural outcomes. More specifically, this research explores how relational variables as well as influence strategies impact creating and appropriating value and ultimately relational satisfaction and relationship continuity. This study makes it possible to make a number of important managerial contributions.

First, the results of this research highlight the need for managers to strategically manage their business relationships in a relational way in order to create and appropriate greater value. Good business relationships reduce conflicts and misunderstandings between supply chain partners and create an environment conducive to transactional efficiency, allowing them to generate and achieve superior and continuous returns (Dyer and Singh, 1998). Second, power is inevitable in any customer-supplier relationship. The results of this study are consistent with previous studies, which have found that coercive power is often destructive for relationships (Leonidou et al., 2008; Hausman and Johnson 2010; Bandara et al., 2017). Therefore, managers must avoid its use in their mainly collaborative relationships, as it can be counterproductive. Indeed, the use of coercion reduces the potential for value creation in the relationship, and may even lead to its rupture (Gulati and Sytch, 2007; Johnson et al., 1993).

Our results also show that non-coercive power can be used to improve value creation in particular and the relationship between the two partners as a whole. Then, our work allows managers to develop a thorough understanding of the two sources of value perception in business relationships and their interaction. This better understanding would allow managers, on the one hand, to protect themselves against the exploitation of partners, by appropriating a fair share of the value created and, on the other hand, to ensure that future opportunities for value creation will not be hindered by excessive appropriation of value on their part.

Finally, the results of this research will enable managers and business leaders to become aware that the development of a positive satisfaction and attitude towards relationship value leads to a stronger relationship with their partners. Executives will thus be able to use the results of our study to recognize that the main driver of future collaborative intent is relational satisfaction, which underscores the importance of effectively managing the value creation and value appropriation processes to ensure the stability and continuity of business relationships.

\section{LIMITATIONS}

The first limitation of this work relates to the relatively small sample size compared to the total population of companies in Morocco. Indeed, the small sample size was put forward as one of the arguments in favour of using the partial least squares (PLS) method. To this end, it would be appropriate to test our causal model with a larger number of observations and using the maximum likelihood method (LISREL) in order to validate the results obtained. The second limitation of this study concerns the adoption of the supplier's perspective alone to assess the business relationship. A dyadic approach, including the views of both partners, would lead to richer results, while allowing to compare the perceptions of the two actors within the dyad. Another potential limitation is the existence of respondent bias, which can occur when a single respondent is asked 
to assess both the nature of the relationship and its performance. By limiting the study to a single client chosen by the respondent, the approach introduces bias into the results, as respondents adopt different criteria to select the relationship in question (Fynes et al., 2005). Finally, a final limitation comes from our multi-sector survey field. Since the distribution of sectors of activity is unequal, it is difficult to compare sectors of activity among themselves. In addition, it is difficult for us to give personalized and specific results to each sector of activity. Instead, we are able to provide general recommendations to companies. However, having a large number of participants from different sectors avoids the problem of endogeneity of results.

\section{REFERENCES}

Abbad, H. (2008). L'orientation à long terme dans le canal de distribution : le cas de la relation entre la grande distribution et les PMI agroalimentaires au Maroc, Thèse de doctorat en Sciences de Gestion, Université de la Méditerranée.

Alejandro, T. B., Souza, D. V., Boles, J. S., Ribeiro, Á. H. P., and Monteiro, P. R. R. (2011). The outcome of company and account manager relationship quality on loyalty, relationship value and performance. Industrial Marketing Management, $40(1)$, $36-43$. https://doi.org/10.1016/j.indmarman.2010.09.008

Anderson, J. C. (1995). Relationships in Business Markets : Exchange Episodes, Value Creation, and Their Empirical Assessment.

Anderson, J. C., and Narus, J. A. (1990). A Model of Distributor Firm and Manufacturer Firm Working Partnerships. Journal of Marketing, 54(1), 42. https://doi.org/10.2307/1252172

Arend, R. J., Wisner, J. D., Arnett, D. B., and Badrinarayanan, V. (2005). Enhancing customer-needs-driven crm strategies: Core selling teams, knowledge management competence, and relationship marketing competence. Elsevier (Vol. 20). https://doi.org/10.1080/08853134.2005.10749068

Athanasopoulou, P. (2009). Relationship quality a critical literature review.

Athanassopoulou, P. (2006). Determining relationship quality in the development of business-to-business financial services. Journal of Business-to-Business Marketing, 13(1), 87-120. https://doi.org/10.1300/J033v13n01

Bandara, S., Leckie, C., Lobo, A., and Hewege, C. (2017). Power and relationship quality in supply chains. Asia Pacific Journal of Marketing and Logistics, 29(3), 501-518. https://doi.org/10.1108/APJML-09-2016-0165

Becker, J., Klein, K., and Wetzels, M. (2012). Hierarchical Latent Variable Models in PLS-SEM : Guidelines for Using Reflective-Formative Type Models. Long Range Planning, 45(5-6), 359-394. https://doi.org/10.1016/j.Irp.2012.10.001

Belaya, V., and Hanf, J. H. (2009). The two sides of power in business-to-business relationships: implications for supply chain management. The Marketing Review, 9(4), 361-381. https://doi.org/10.1362/146934709X479926

Benton, W. C., and Maloni, M. (2005). The influence of power driven buyer/seller relationships on supply chain satisfaction. Journal of Operations Management, 23(1), 1-22. https://doi.org/10.1016/j.jom.2004.09.002

Billitteri, C., Nigro, G. Lo, and Perrone, G. (2013). How risk influences the choice of governance mode in biopharmaceutical inter-firm relationships. International Business Review, 22(6), 932-950. https://doi.org/10.1016/j.ibusrev.2013.01.011

Blau, P. M. (1960). A Theory of Social Integration. American Journal of Sociology, 65(6), 545-556. https://doi.org/10.1086/222785

Blau, P. M. (2017). Exchange and Power in Social Life. Routledge. https://doi.org/10.4324/9780203792643

Brito, R. P., and Miguel, P. L. S. (2016). Power, Governance, and Value in Collaboration: Differences between Buyer and Supplier Perspectives. International Journal of Laboratory Hematology, 38(1), 42-49. https://doi.org/10.1111/ijlh.12426

Carson, S. J., Devinney, T. M., Dowling, G. R., and John, G. (1999). Understanding Institutional Designs within Marketing Value Systems. Journal of Marketing, 63(4_suppl1), 115-130. https://doi.org/10.1177/00222429990634s112

Chadwick-Jones, J. (1976). Social exchange theory: Its structure and influence in social psychology.

Chancerel, J.-L. (1988). Théorie de la mesure et objets. Espace Géographique, 17(3), 218-231. https://doi.org/10.3406/spgeo.1988.2780

Chandon, J.-L. (2007). Théorie de la mesure et construction d'échelles. Recherche.

Chen, P.-Y., Chen, K.-Y., and Wu, L.-Y. (2017). The impact of trust and commitment on value creation in asymmetric buyer-seller relationships: the mediation effect of specific asset investments. Journal of Business and Industrial Marketing, 32(3), 457-471. https://doi.org/10.1108/JBIM-09-2014-0171

Cherni, M., and Leroux, V. (2015). Dynamique relationnelle et impact sur la création- appropriation de la valeur dans les partenariats clientfournisseur Dynamique relationnelle et impact sur la création- appropriation de la valeur dans les partenariats client- fournisseur, 1-25.

Chicksand, D., and Rehme, J. (2018). Total value in business relationships: exploring the link between power and value appropriation. Journal of Business and Industrial Marketing, 33(2), 174-182. https://doi.org/10.1108/JBIM-05-2016-0100 
Coff, R. W. (1999). When Competitive Advantage Doesn't Lead to Performance: The Resource-Based View and Stakeholder Bargaining Power. Organization Science, 10(2), 119-133. https://doi.org/10.1287/orsc.10.2.119

Cox, A., Watson, G., Lonsdale, C., and Sanderson, J. (2004). Managing appropriately in power regimes : Relationship and performance management in 12 supply chain cases Supply Chain Management: An International Journal cases Article information :, (January 2015). https://doi.org/10.1108/13598540410560748

Crook, T. R., and Combs, J. G. (2007). Sources and consequences of bargaining power in supply chains, 25, 546-555. https://doi.org/10.1016/j.jom.2006.05.008

Crosby, L. A., Evans, K. R., and Cowles, D. (1990). Relationship Quality in Services Selling: An Interpersonal Influence Pers pective. Journal of Marketing, 54(3), 68-81. https://doi.org/10.1177/002224299005400306

Deligonul, S., Kim, D., Roath, A. S., and Cavusgil, E. (2006). The Achilles' heel of an enduring relationship: Appropriation of rents between a manufacturer and its foreign distributor. Journal of Business Research, 59(7), 802-810. https://doi.org/10.1016/j.jbusres.2005.11.004

Dion, P., and Goodman, L. (2001). The Determinants of Commitment in the Distributor - Manufacturer Relationship. Industrial Marketing Management, 30, 287-300. Retrieved from https://www.sciencedirect.com/science/article/pii/S0019850199000929

Doney, P. M., and Cannon, J. P. (1997). An Examination of the Nature of Trust in Buyer-Seller Relationships. Journal of Marketing, 61(2), 3551. https://doi.org/10.1177/002224299706100203

Dwyer, R., Schurr, F., Paul, H., and Oh, S. (1987). Buyer-Seller Developing Relationships. American Journal of Marketing, Vol. 51, No. 2 (Apr., 1987), Pp. 11-27, 51(2), 11-27.

Dyer, J. H., and Chu, W. (2011). The determinants of trust in supplier-automaker relationships in the US, Japan, and Korea. Journal of International Business Studies, 42(1), 10-27. https://doi.org/10.1057/jibs.2010.34

Dyer, J. H., and Singh, H. (1998). The Relational View: Cooperative Strategy and Sources of Interorganizational Competitive Advantage. Academy of Management Review, 23(4), 660-679. https://doi.org/10.5465/amr.1998.1255632

Ellegaard, Chris; Medlin, Christopher John; Geersbro, J. (2014). Value Appropriation in Business Exchange - Literature Review and Future Research Opportunities Introduction. Journal of Business and Industrial Marketing, 29(April), 185-198.

Emerson, R. M. (1962). Power-dependence relations. American Sociological Review, 27(1), 31-41. Retrieved from https://www.jstor.org/stable/2089716

Fang, E., Palmatier, R. W., and Evans, K. R. (2008). Influence of customer participation on creating and sharing of new product value. Journal of the Academy of Marketing Science, 36(3), 322-336. https://doi.org/10.1007/s11747-007-0082-9

Ferrer, M., Santa, R., Hyland, P. W., and Bretherton, P. (2010). Relational factors that explain supply chain relationships. Asia Pacific Journal of Marketing and Logistics, 22(3), 419-440. https://doi.org/10.1108/13555851011062304

Field, A. (2005). Discovering statistics using SPSS . Thousand Oaks, CA, US.

Fishbein, M., and Ajzen, I. (1977). Belief, attitude, intention, and behavior: An introduction to theory and research. Retrieved from https://philarchive.org/archive/FISBAI

Fornell, C., and Bookstein, F. L. (1982). Two Structural Equation Models: LISREL and PLS Applied to Consumer Exit-Voice Theory. Journal of Marketing Research, 19(4), 440-452. https://doi.org/10.1177/002224378201900406

Fornell, C., and Larcker, D. F. (1981). Evaluating Structural Equation Models with Unobservable Variables and Measurem ent Error. Journal of Marketing Research, 18(1), 39. https://doi.org/10.2307/3151312

Francis, M., Fisher, R., Thomas, A., and Rowlands, H. (2014). The meaning of 'value' in purchasing, logistics and operations management. International Journal of Production Research, 52(22), 6576-6589. https://doi.org/10.1080/00207543.2014.903349

Frazier, G. L., and Rody, R. C. (1991). The Use of Influence Strategies in Interfirm Relationships in Industrial Product Channels. Journal of Marketing, 55(1), 52-69. https://doi.org/10.1177/002224299105500105

Frazier, G. L., and Summers, J. O. (1986). Perceptions of Interfirm Power and its use within a Franchise Channel of Distribution. Journal of Marketing Research, 23(2), 169-176. https://doi.org/10.1177/002224378602300209

Fynes, B., Voss, C., and de Búrca, S. (2005). The impact of supply chain relationship dynamics on manufacturing performance. International Journal of Operations and Production Management, 25(1), 6-19. https://doi.org/10.1108/01443570510572213

Ganesan, S. (1994). Determinants of Long-Term in Buyer-Seller Orientation Relationships. The Journal of Marketing, 58(April), 1-19. https://doi.org/10.2307/1252265

Gelderman, C. J., Semeijn, J., and De Zoete, R. (2008). The use of coercive influence strategies by dominant suppliers. Journal of Purchasing and Supply Management, 14(4), 220-229. https://doi.org/10.1016/j.pursup.2008.06.003

Griffith, D. A., Harvey, M. G., and Lusch, R. F. (2006). Social exchange in supply chain relationships: The resulting benefits of procedural and distributive justice. Journal of Operations Management. https://doi.org/10.1016/j.jom.2005.03.003 
Gulati, R., and Sytch, M. (2007). Dependence Asymmetry and Joint Dependence in Interorganizational Relationships: Effects of Embeddedness on a Manufacturer's Performance in Procurement Relationships. Administrative Science Quarterly, 52(1), 32-69. https://doi.org/10.2189/asqu.52.1.32

Hair, J. F., Sarstedt, M., Ringle, C. M., and Gudergan, S. P. (2018). Advanced Issues in Partial Least Squares Equation Modeling.

Hausman, A., and Johnston, W. J. (2010). Industrial Marketing Management The impact of coercive and non-coercive forms of in fl uence on trust , commitment, and compliance in supply chains. Industrial Marketing Management, 39(3), 519-526. https://doi.org/10.1016/j.indmarman.2009.05.007

Henneberg, S., Jiang, Z., Shiu, E., and Naude, P. (2016). Relationship Quality in Business to Business Relationships-Reviewing the Current Literatures and Proposing a New Measurement Model. Psychology and Marketing, 33(4), 297-313. https://doi.org/10.1002/mar.20876

Homans, G. C. (1958). Social Behavior as Exchange. American Journal of Sociology, 63(6), 597-606. https://doi.org/10.1086/222355

Jap, S. D. (2001). "Pie Sharing" in Complex Collaboration Contexts. Journal of Marketing Research, 38(1), 86-99. https://doi.org/10.1509/jmkr.38.1.86.18827

JF Hair Jr, GTM Hult, C Ringle, M. S. (2014). A Primer on Partial Least Squares Structural Equation Modeling. sage publication (Vol. 46). https://doi.org/10.1016/j.Irp.2013.01.002

JF Hair Jr, GTM Hult, C Ringle, M. S. (2017). A Primer on Partial Least Squares Structural Equation Modeling. sage publication. https://doi.org/10.1016/j.Irp.2013.01.002

Johnson, J. L., Sakano, T., Cote, J. A., and Onzo, N. (1993). The Exercise of Interfirm Power and Its Repercussions in U.S.-Japanese Channel Relationships. Journal of Marketing, 57(2), 1-10. https://doi.org/10.1177/002224299305700201

Jonsson, P., and Zineldin, M. (2003). Achieving high satisfaction in supplier-dealer working relationships. Supply Chain Management: An International Journal, 8(3), 224-240. https://doi.org/10.1108/13598540310484627

Kale, P., Singh, H., and Perlmutter, H. (2000). Learning and protection of proprietary assets in strategic alliances: building relational capital. Strategic Management Journal, 21(3), 217-237. https://doi.org/10.1002/(SICI)1097-0266(200003)21:3<217::AID-SMJ95>3.0.CO;2-Y

Kang, J. (2013). Value Creation and Appropriation in Strategic Alliances: Roles of Resource Characteristics and Structural Po sition in Alliance Network. Business and Management Review, 3(02), 1-9.

Krause, D. R., and Ellram, L. M. (1997). Success factors in supplier development. International Journal of Physical Distribution and Logistics Management, 27(1), 39-52. https://doi.org/10.1108/09600039710162277

Kumar, N., Scheer, L. K., and Steenkamp, J.-B. E. M. (1995). The Effects of Perceived Interdependence on Dealer Attitudes. Journal of Marketing Research, 32(3), 348. https://doi.org/10.2307/3151986

Lacoste, S., and Blois, K. (2015). Suppliers' power relationships with industrial key customers. Journal of Business and Industrial Marketing, 30(5). https://doi.org/10.1108/JBIM-03-2013-0057

Lacroux, A. (2009). L'Analyse Des Modeles De Relations Structurelles Par La Methode Pls : Une Approche Emergente Dans La Recherche. In XXème congrès de l'AGRH (pp. 1-27).

Lambe, C. J., Wittmann, C. M., and Spekman, R. E.. Social Exchange Theory and Research on Business-to-Business Relational Exchange. Journal of Business-to-Business Marketing ISSN:, 0628(March), 0-36. https://doi.org/10.1300/J033v08n03

Leonidou, L. C., Talias, M. A., and Leonidou, C. N. (2008). Exercised power as a driver of trust and commitment in cross-border industrial buyer - seller relationships, 37, 92-103. https://doi.org/10.1016/j.indmarman.2007.08.006

Lindgreen, Adam, Martin K. Hingley, D. B. G. and R. E. M. (2012). Value in Business and Industrial Marketing: Past, Present, and Future. Industrial Marketing Management, 41(1), 207-214.

Lindgreen, A., and Wynstra, F. (2005). Value in business markets: What do we know? Where are we going? Industrial Marketing Management, 34(7 SPEC. ISS.), 732-748. https://doi.org/10.1016/j.indmarman.2005.01.001

Liu, Y., Li, Y., and Zhang, L. (2010). Control mechanisms across a buyer-supplier relationship quality matrix. Journal of Business Research, 63(1), 3-12. https://doi.org/10.1016/j.jbusres.2009.01.005

Maloni, M., and Benton, W. C. (2000). Power influences in the Supply Chain. Journal of Business Logistics, 21(I), 49-73. https://doi.org/10.1017/СBO9781107415324.004

McDonald, F. (1999). The Importance of Power in Partnership Relationships. Journal of General Management, 25(1), 43-59. https://doi.org/10.1177/030630709902500103

Miguel, P. L. S., Brito, L. A. L., Fernandes, A. R., Tescari, F. V. C. S., and Martins, G. S. (2014). Relational value creation and appropriation in buyer-supplier relationships. International Journal of Physical Distribution and Logistics Management, 44(7), 559-576. https://doi.org/10.1108/IJPDLM-09-2012-0291

Mizik, N., and Jacobson, R. (2003). The Financial Implications of Shifts inand Value Appropriation : Journal of Marketing, 67(January), 63-76. 
Morgan, R. M., and Hunt, S. D. (1994). Theory of Relationship Marketing, 58(3), 20-38.

Nunnally, J. (1978). Psychometric theory (2nd edit.) mcgraw-hill.

Nunnally, J., and IH Bernstein. (1994). Psychometric Theory. McGraw-Hill New York, NY.

Nyaga, G. N., Lynch, D. F., Marshall, D., and Ambrose, E. (2013). Power asymmetry, adaptation and collaboration in dyadic relationships involving a powerful partner. Journal of Supply Chain Management, 49(3), 42-65. https://doi.org/10.1111/jscm.12011

Nyaga, G. N., and Whipple, J. M. (2011). Relationship quality and performance outcomes: Achieving a sustainable competitive advantage. Journal of Business Logistics, 32(4), 345-360. https://doi.org/10.1111/j.0000-0000.2011.01030.x

Palmatier, R. W. (2008). Interfirm Relational Drivers of Customer Value. Journal of Marketing, 72(4), 76-89. https://doi.org/10.1509/jmkg.72.4.76

Ringle, C. M., Wende, S., and Becker, J.-M. (2015). "SmartPLS 3." Boenningstedt. SmartPLS GmbH.

Sandberg, E., Pal, R., and Hemilä, J. (2018). Exploring value creation and appropriation in the reverse clothing supply chain. International Journal of Logistics Management, 29(1), 90-109. https://doi.org/10.1108/IJLM-10-2016-0241

Scheer L.K., Kumar N., and Steenkamp J.B.E.M. (2003). Reactions to perceived inequity in US and Dutch interorganizational relationships. Academy of Management Journal, 46(3), 303-316.

Skinner, Steven J., Gassenheimer, Jule B., and Kelley, S. W. (1992). Cooperation in supplier-dealer relations. Journal of Retailing.

Sosik, J. J., Kahai, S. S., and Piovoso, M. J. (2009). Silver Bullet or Voodoo Statistics? Group and Organization Management, 34(1), 5-36. https://doi.org/10.1177/1059601108329198

Tescari, F. C., and Brito, L. A. L. (2016). Value Creation and Capture in Buyer-Supplier Relationships: a New Perspective. RAE Revista de Administracao de Empresas, 56, 474-489. https://doi.org/10.1590/S0034-759020160503

Thibaut, J. W., and Kelley, H. H. (2017). The Social Psychology of Groups. The American Catholic Sociological Review, $20(4), 345$. https://doi.org/10.2307/3709294

Ulaga, W., and Eggert, A. (2006). Relationship value and relationship quality: Broadening the nomological network of business-to-business relationships. European Journal of Marketing, 40(3-4), 311-327. https://doi.org/10.1108/03090560610648075

Wagner, S. M., Eggert, A., and Lindemann, E. (2010). Creating and appropriating value in collaborative relationships. Journal of Business Research, 63(8), 840-848. https://doi.org/10.1016/j.jbusres.2010.01.004

Wagner, S. M., and Lindemann, E. (2008). Determinants of value sharing in channel relationships. Journal of Business and Industrial Marketing, 23(8), 544-553. https://doi.org/10.1108/08858620810913353

Walter, A., and Ritter, T. (2003). The influence of adaptations, trust, and commitment on value-creating functions of customer relationships. Journal of Business and Industrial Marketing, 18(4-5), 353-365. https://doi.org/10.1108/08858620310480250

Wathne, K. H., and Heide, J. B. (2000). Opportunism in Interfirm Relationships: Forms, Outcomes, and Solutions. Journal of Marketing, 64(4), 36-51. https://doi.org/10.1509/jmkg.64.4.36.18070

Wilkinson, I. F. (1979). Power and satisfaction in channels of distribution. Journal of Retailing.

Yan, T., and Wagner, S. M. (2017). Do what and with whom? value creation and appropriation in inter-organizational new product development projects. International Journal of Production Economics, 191(May), 1-14. https://doi.org/10.1016/j.ijpe.2017.05.010

Zhao, S., Yu, H., Xu, Y., and Bi, Z. (2014). Relationship-specific investment, value creation, and value appropriation in cooperative innovation. Information Technology and Management, 15(2), 119-130. https://doi.org/10.1007/s10799-014-0174-4

Zhao, X., Lynch, J. G., and Chen, Q. (2011). Reconsiderer Baron et Kenny: mythes et verites a propos de l'analyse de mediation. Recherche et Applications En Marketing, 26(1), 81-95. https://doi.org/10.1177/076737011102600105 
Appendix 1: Item Formulations

\begin{tabular}{|c|c|}
\hline \multicolumn{2}{|r|}{ TRUST } \\
\hline Trust 1 & Our main customer kept promises it made to our firm \\
\hline Trust 2 & Our main customer was always honest to us. \\
\hline Trust 3 & We believed the information that our main customer provided us. \\
\hline Trust 4 & Our main customer was genuinely concerned that our business succeeded. \\
\hline Trust 5 & $\begin{array}{l}\text { When making important decisions, our main customer considered our welfare as well as its } \\
\text { own. }\end{array}$ \\
\hline Trust 6 & We trusted our main customer keeps our best interests in mind. \\
\hline Trust 7 & Our main customer was trustworthy. \\
\hline \multicolumn{2}{|r|}{ COMMITMENT } \\
\hline COMMIT1 & The relationship with our main customer is something to which we are very committed \\
\hline COMMIT2 & The relationship with our main customer is very important to our business \\
\hline COMMIT3 & $\begin{array}{l}\text { The relationship with our main customer is something our business intends to maintain } \\
\text { indefinitely }\end{array}$ \\
\hline COMMIT4 & The relationship with our main customer is very much like being family \\
\hline COMMIT5 & The relationship with our main customer is something our business really cares about \\
\hline COMMIT6 & $\begin{array}{l}\text { The relationship with our main customer deserves our business' maximum effort to } \\
\text { maintain }\end{array}$ \\
\hline \multicolumn{2}{|r|}{ COMMUNICATION } \\
\hline COMMIT1 & $\begin{array}{l}\text { In this relationship, it is expected that any information that might help our main customer } \\
\text { will be provided to them }\end{array}$ \\
\hline COMMIT2 & $\begin{array}{l}\text { Exchange of information in this relationship takes place frequently and informally and not } \\
\text { only according to a pre-specified agreement }\end{array}$ \\
\hline COMMIT3 & $\begin{array}{l}\text { It is expected that the parties will provide proprietary information if it can help the other } \\
\text { party }\end{array}$ \\
\hline COMMIT4 & $\begin{array}{l}\text { It is expected that we will keep each other informed about events or changes that affect the } \\
\text { other party }\end{array}$ \\
\hline COMMIT5 & $\begin{array}{l}\text { The communication effort between our main customer and our firm involves many inter- } \\
\text { firm contacts }\end{array}$ \\
\hline COMMIT6 & Exchange of information in this relationship takes place in a timely manner \\
\hline \multicolumn{2}{|r|}{$\begin{array}{l}\text { COERCIVE POWER } \\
\end{array}$} \\
\hline CPW1 & $\begin{array}{l}\text { Failure to comply with the requests of our main customer will result in financial and other } \\
\text { penalties against our company. }\end{array}$ \\
\hline CPW2 & $\begin{array}{l}\text { Our main customer threatens to withdraw from what they originally promised if we do not } \\
\text { comply with their request. }\end{array}$ \\
\hline CPW3 & Our main customer threatens to take legal action if we do not comply with their requests. \\
\hline CPW4 & $\begin{array}{l}\text { Our main customer withholds important support for our firm, in requesting compliance with } \\
\text { their demand. }\end{array}$ \\
\hline CPW5 & $\begin{array}{l}\text { Our main customer threatens to deal with another supplier, in order to make us submit to } \\
\text { their demand. }\end{array}$ \\
\hline \multicolumn{2}{|r|}{ NON-COERCIVE POWER } \\
\hline NCPW1 & $\begin{array}{l}\text { Our main customer offers specific incentives to us when we are reluctant to cooperate with } \\
\text { them. }\end{array}$ \\
\hline NCPW2 & $\begin{array}{l}\text { Our main customer has the upper hand in the relationship due to power granted to them by } \\
\text { the contract. }\end{array}$ \\
\hline NCPW3 & $\begin{array}{l}\text { Our main customer demands our compliance because of knowing that we appreciate and } \\
\text { admire them. }\end{array}$ \\
\hline NCPW4 & $\begin{array}{l}\text { Our main customer use their unique competence to make our company accept their } \\
\text { recommendations }\end{array}$ \\
\hline NCPW5 & $\begin{array}{l}\text { Our main customer partner withholds critical information concerning the relationship to } \\
\text { better control our company. }\end{array}$ \\
\hline \multicolumn{2}{|r|}{ VALUE CREATION AND VALUE APPROPRIATION } \\
\hline Input supplier & Our company's contributions to the relationship \\
\hline Input customer & Customer X's contributions to the relationship \\
\hline
\end{tabular}




\begin{tabular}{|c|c|}
\hline Outcome supplier & The outcomes we received from the relationship \\
\hline Outcome customer & The outcomes Customer $\mathrm{X}$ received from the relationship \\
\hline Tangible input supplier & Our company's tangible (financial and personnel) contributions to the relationship \\
\hline Tangible input customer & Customer X's tangible (financial and personnel) contributions to the relationship \\
\hline $\begin{array}{l}\text { Tangible outcome } \\
\text { supplier }\end{array}$ & The tangible (financial) outcomes we received from the relationship \\
\hline $\begin{array}{l}\text { Tangible outcome } \\
\text { customer }\end{array}$ & The tangible (financial) outcomes customer $\mathrm{X}$ received from the relationship \\
\hline Intangible input supplier & Our company's intangible (know-how and patents) contributions to the relationship \\
\hline $\begin{array}{l}\text { Intangible input } \\
\text { customer }\end{array}$ & Customer X's intangible (know-how and patents) contributions to the relationship \\
\hline $\begin{array}{l}\text { Intangible outcome } \\
\text { supplier }\end{array}$ & The intangible (know-how and patents) outcomes we received from the relationship \\
\hline $\begin{array}{l}\text { Intangible outcome } \\
\text { customer }\end{array}$ & The intangible (know-how and patents) outcomes customer $\mathrm{X}$ received from the relationship \\
\hline \multicolumn{2}{|r|}{ RELATIONAL SATISFACTION } \\
\hline SATISFAC1 & We were very satisfied with the relationship with our main customer \\
\hline SATISFAC2 & We were pleased to work with our main customer \\
\hline SATISFAC3 & The relationship with our main customer was very favorable for us \\
\hline \multicolumn{2}{|r|}{ RELATIONSHIP CONTINUITY } \\
\hline CONTIN1 & We expect our relationship with our main customer to continue for a long time \\
\hline CONTIN2 & Renewal of relationship with our main customer is virtually automatic \\
\hline CONTIN3 & It is unlikely that our firm will still be doing business with our main customer in two years \\
\hline
\end{tabular}




\begin{tabular}{|c|c|c|c|c|c|c|c|c|c|c|}
\hline \multicolumn{4}{|c|}{ Appendix 2 : Discriminant Validity } & \multicolumn{7}{|c|}{ Saad, Noureddine } \\
\hline & \begin{tabular}{|l|} 
Value \\
appropriation
\end{tabular} & Communication & Trust & $\begin{array}{l}\text { Relationship } \\
\text { continuity }\end{array}$ & \begin{tabular}{|l|}
$\begin{array}{l}\text { Value } \\
\text { creation }\end{array}$ \\
\end{tabular} & Commitment & $\begin{array}{l}\text { Coercive } \\
\text { power }\end{array}$ & $\begin{array}{l}\text { Non Coercive } \\
\text { power }\end{array}$ & \begin{tabular}{|l|}
$\begin{array}{l}\text { Relationship } \\
\text { quality }\end{array}$ \\
\end{tabular} & Satisfaction \\
\hline VAL SUPL 1 & 0.959 & 0.318 & 0.347 & 0.438 & 0.808 & 0.287 & -0.191 & 0.179 & 0.373 & 0.490 \\
\hline VAL SUPL 2 & 0.961 & 0.280 & 0.350 & 0.420 & 0.854 & 0.221 & -0.292 & 0.221 & 0.335 & 0.478 \\
\hline COMM2 & 0.275 & 0.700 & 0.458 & 0.325 & 0.309 & 0.453 & -0.243 & 0.049 & 0.619 & 0.240 \\
\hline COMM2 & 0.275 & 0.700 & 0.458 & 0.325 & 0.309 & 0.453 & -0.243 & 0.049 & 0.619 & 0.240 \\
\hline СОММЗ & 0.318 & 0.770 & 0.441 & 0.364 & 0.292 & 0.555 & -0.194 & 0.059 & 0.675 & 0.402 \\
\hline СОММЗ & 0.318 & 0.770 & 0.441 & 0.364 & 0.292 & 0.555 & -0.194 & 0.059 & 0.675 & 0.402 \\
\hline COMM4 & 0.265 & 0.875 & 0.490 & 0.340 & 0.309 & 0.647 & -0.136 & 0.048 & 0.768 & 0.313 \\
\hline COMM4 & 0.265 & 0.875 & 0.490 & 0.340 & 0.309 & 0.647 & -0.136 & 0.048 & 0.768 & 0.313 \\
\hline СOMM5 & 0.191 & 0.800 & 0.427 & 0.212 & 0.214 & 0.554 & 0.023 & 0.206 & 0.678 & 0.233 \\
\hline COMM5 & 0.191 & 0.800 & 0.427 & 0.212 & 0.214 & 0.554 & 0.023 & 0.206 & 0.678 & 0.233 \\
\hline СОМM6 & 0.217 & 0.883 & 0.449 & 0.279 & 0.212 & 0.584 & -0.030 & 0.096 & 0.729 & 0.293 \\
\hline COMM6 & 0.217 & 0.883 & 0.449 & 0.279 & 0.212 & 0.584 & -0.030 & 0.096 & 0.729 & 0.293 \\
\hline TRUST1 & 0.248 & 0.508 & 0.794 & 0.318 & 0.302 & 0.495 & -0.147 & 0.104 & 0.712 & 0.424 \\
\hline TRUST 1 & 0.248 & 0.508 & 0.794 & 0.318 & 0.302 & 0.495 & -0.147 & 0.104 & 0.712 & 0.424 \\
\hline TRUST 2 & 0.238 & 0.365 & 0.725 & 0.373 & 0.247 & 0.467 & -0.328 & 0.088 & 0.620 & 0.393 \\
\hline TRUST 2 & 0.238 & 0.365 & 0.725 & 0.373 & 0.247 & 0.467 & -0.328 & 0.088 & 0.620 & 0.393 \\
\hline TRUST 3 & 0.274 & 0.463 & 0.765 & 0.289 & 0.321 & 0.503 & -0.277 & 0.159 & 0.686 & 0.371 \\
\hline TRUST 3 & 0.274 & 0.463 & 0.765 & 0.289 & 0.321 & 0.503 & -0.277 & 0.159 & 0.686 & 0.371 \\
\hline TRUST 4 & 0.227 & 0.396 & 0.728 & 0.302 & 0.248 & 0.355 & -0.294 & 0.095 & 0.590 & 0.351 \\
\hline TRUST 4 & 0.227 & 0.396 & 0.728 & 0.302 & 0.248 & 0.355 & -0.294 & 0.095 & 0.590 & 0.351 \\
\hline TRUST 5 & 0.311 & 0.386 & 0.803 & 0.251 & 0.328 & 0.304 & -0.285 & 0.286 & 0.601 & 0.464 \\
\hline TRUST 5 & 0.311 & 0.386 & 0.803 & 0.251 & 0.328 & 0.304 & -0.285 & 0.286 & 0.601 & 0.464 \\
\hline TRUST 6 & 0.361 & 0.438 & 0.794 & 0.314 & 0.373 & 0.431 & -0.279 & 0.259 & 0.663 & 0.451 \\
\hline
\end{tabular}




\begin{tabular}{|c|c|c|c|c|c|c|c|c|c|c|}
\hline TRUST 6 & 0.361 & 0.438 & 0.794 & 0.314 & 0.373 & 0.431 & -0.279 & 0.259 & 0.663 & 0.451 \\
\hline TRUST 7 & 0.302 & 0.452 & 0.791 & 0.192 & 0.306 & 0.453 & -0.174 & 0.078 & 0.675 & 0.477 \\
\hline TRUST 7 & 0.302 & 0.452 & 0.791 & 0.192 & 0.306 & 0.453 & -0.174 & 0.078 & 0.675 & 0.477 \\
\hline CONTIN 1 & 0.423 & 0.370 & 0.347 & 0.889 & 0.471 & 0.536 & -0.232 & 0.144 & 0.484 & 0.586 \\
\hline CONTIN 2 & 0.405 & 0.339 & 0.357 & 0.837 & 0.450 & 0.395 & -0.406 & 0.204 & 0.425 & 0.438 \\
\hline CONTIN 3 & 0.310 & 0.242 & 0.257 & 0.854 & 0.389 & 0.322 & -0.323 & 0.067 & 0.319 & 0.415 \\
\hline VALUE 1 & 0.845 & 0.335 & 0.403 & 0.490 & 0.975 & 0.334 & -0.298 & 0.218 & 0.421 & 0.503 \\
\hline VAL UE 2 & 0.844 & 0.306 & 0.365 & 0.507 & 0.975 & 0.293 & -0.312 & 0.240 & 0.378 & 0.498 \\
\hline COMMIT 1 & 0.222 & 0.558 & 0.502 & 0.434 & 0.304 & 0.828 & -0.177 & 0.054 & 0.729 & 0.359 \\
\hline COMMIT 1 & 0.222 & 0.558 & 0.502 & 0.434 & 0.304 & 0.828 & -0.177 & 0.054 & 0.729 & 0.359 \\
\hline COMMIT 2 & 0.248 & 0.579 & 0.463 & 0.394 & 0.275 & 0.857 & -0.069 & 0.082 & 0.730 & 0.332 \\
\hline COMMIT 2 & 0.248 & 0.579 & 0.463 & 0.394 & 0.275 & 0.857 & -0.069 & 0.082 & 0.730 & 0.332 \\
\hline COMMIT 3 & 0.212 & 0.595 & 0.444 & 0.447 & 0.298 & 0.868 & -0.086 & 0.216 & 0.732 & 0.343 \\
\hline COMMIT 3 & 0.212 & 0.595 & 0.444 & 0.447 & 0.298 & 0.868 & -0.086 & 0.216 & 0.732 & 0.343 \\
\hline COMMIT 4 & 0.193 & 0.532 & 0.450 & 0.335 & 0.239 & 0.756 & -0.192 & 0.068 & 0.669 & 0.308 \\
\hline COMMIT 4 & 0.193 & 0.532 & 0.450 & 0.335 & 0.239 & 0.756 & -0.192 & 0.068 & 0.669 & 0.308 \\
\hline COMMIT 6 & 0.220 & 0.618 & 0.469 & 0.454 & 0.219 & 0.838 & -0.102 & 0.008 & 0.739 & 0.301 \\
\hline СOMMIT 6 & 0.220 & 0.618 & 0.469 & 0.454 & 0.219 & 0.838 & -0.102 & 0.008 & 0.739 & 0.301 \\
\hline$C P W 1$ & -0.138 & 0.005 & -0.152 & -0.234 & -0.218 & 0.017 & 0.796 & 0.101 & -0.058 & -0.207 \\
\hline CPW 2 & -0.277 & -0.105 & -0.253 & -0.297 & -0.307 & -0.080 & 0.890 & 0.004 & -0.178 & -0.212 \\
\hline CPW 3 & -0.171 & -0.197 & -0.248 & -0.380 & -0.233 & -0.231 & 0.799 & 0.071 & -0.265 & -0.248 \\
\hline CPW 4 & -0.126 & -0.090 & -0.241 & -0.222 & -0.199 & -0.111 & 0.771 & 0.066 & -0.178 & -0.144 \\
\hline CPW 5 & -0.260 & -0.161 & -0.395 & -0.319 & -0.281 & -0.189 & 0.777 & -0.035 & -0.300 & -0.382 \\
\hline NCPW 1 & 0.168 & 0.151 & 0.285 & 0.206 & 0.221 & 0.143 & -0.154 & 0.771 & 0.232 & 0.333 \\
\hline NCPW 3 & 0.191 & 0.053 & 0.098 & 0.094 & 0.181 & 0.012 & 0.114 & 0.833 & 0.066 & 0.248 \\
\hline
\end{tabular}




\begin{tabular}{|c|c|c|c|c|c|c|c|c|c|c|}
\hline NCPW 4 & 0.140 & 0.047 & 0.044 & 0.068 & 0.152 & 0.080 & 0.214 & 0.818 & 0.066 & 0.090 \\
\hline SATISFAC1 & 0.436 & 0.320 & 0.478 & 0.527 & 0.440 & 0.379 & -0.293 & 0.209 & 0.464 & 0.898 \\
\hline SATISFAC2 & 0.482 & 0.355 & 0.497 & 0.546 & 0.484 & 0.370 & -0.280 & 0.296 & 0.482 & 0.951 \\
\hline SATISFAC3 & 0.478 & 0.342 & 0.530 & 0.501 & 0.499 & 0.348 & -0.265 & 0.315 & 0.483 & 0.921 \\
\hline
\end{tabular}




\section{Appendix 3:}

Assessment of the reliability and validity of convergence of the global construct of relationship quality

\begin{tabular}{|l|c|c|c|}
\hline Elements & Factor loading & $\begin{array}{c}\text { Factor loading } \\
\text { squared }\end{array}$ & Error variance = 1 - Factor loading squared \\
\hline Trust & 0,846 & 0,715716 & 0,284284 \\
\hline Commitment & 0,868 & 0,753424 & 0,246576 \\
\hline Communication & 0,859 & 0,737881 & 0,262119 \\
\hline Total factor loading & 2,573 & 2,207021 & 0,792979 \\
\hline Total factor loading squared & 6,620329 & & $\mathbf{7 , 4 1 3 3 0 8}$ \\
\hline $\begin{array}{l}\text { Total factor loading squared + } \\
\text { total error variance }\end{array}$ & & & $\mathbf{0 , 8 5 7}$ \\
\hline AVE ${ }^{1}$ & & & $\mathbf{0 , 8 9 3}$ \\
\hline CR & & & \\
\hline
\end{tabular}

\footnotetext{
${ }^{1} \mathrm{AVE}=$ (Total factor loading / number of factor)

${ }^{2} \mathrm{CR}=$ Total factor loading squared $/$ (Total factor loading squared + Total Error variance)
} 